\title{
PENGARUH INISIASI MENYUSU DINI TERHADAP FETAL OUTCOME TAHUN 2017
}

\author{
Hotma Sauhur Hutagaol ${ }^{1}$ \\ Jurusan Kebidanan Padangsidimpuan \\ Politeknik Kesehatan Kemenkes Medan Jalan Jamin Ginting KM 13,5
}

\begin{abstract}
Abstrak
Rerata suhu aksila ibu satu jam persalinan pada kelompok IMD lebih tinggi Hipotermia merupakan penyebab utama kesakitan dan kematian bayi baru lahir di negara berkembang. Salah satu asuhan essensial untuk mencegah hipotermi adalah dengan melaksanakan inisiasi menyusu dini. Tujuan penelitian ini adalah untuk mengetahui pengaruh inisiasi menyusu dini terhadap fetal outcome. Penelitian ini merupakan studi cross-sectional comparatif. Alat yang digunakan pada penelitian berupa termometer kulit digital, termometer digital dan jam second. Dilakukan observasi bayi yang lahir dengan persalinan normal yang dilaksanakan IMD atau tidak, dan kemudian dilakukan pengukuran apgar score, suhu aksila bayi pada kedua kelompok. Data dianalisa menggunakan uji mann-whitney, dan nilai $p<0.05$ dianggap bermakna secara statistik. Rerata Apgar Score pada kelompok IMD adalah 9,8 \pm 0,3 dan pada kelompok non IMD adalah 9,3 $\pm 0,4, p$ value $0,001(>0,05)$. Rerata suhu aksila bayi pada kelompok IMD adalah $37,2 \pm 0,1^{\circ} \mathrm{C}$ dan rerata suhu aksila bayi pada kelompok non IMD adalah $37,0 \pm 0,2^{\circ} \mathrm{C}, p$ value $0,020(<0,05)$.
\end{abstract}

Kata kunci : Inisiasi Menyusu Dini (IMD), Fetal Outcome

\section{PENDAHULUAN}

Masa transisi bayi merupakan masa yang sangat kritis pada bayi dalam upaya untuk dapat bertahan hidup, bayi baru lahir harus beradaptasi dengan kehidupan di luar uterus bayi baru lahir harus beradaptasi dengan kehidupan di luar uterus, antara lain pengaturan suhu, perubahan sistem pernafasan, perubahan sistem peredaran darah, metabolisme glukosa dan sistem kekebalan tubuh atau imun. Bila pada masa ini bayi tidak dapat melewati masa transisi dengan baik maka dapat terjadi komplikasi seperti hipoksia, hipotermia, hipoglikemia, asfiksia bahkan kematian bayi baru lahir ${ }^{1}$.

Perubahan dari dalam uterus keluar tubuh ibu yang jauh lebih dingin bila dibandingkan suhu didalam uterus yang relatif lebih hangat sekitar $37^{\circ} \mathrm{C}$, dengan suhu ruangan yang normalnya $25^{\circ} \mathrm{C}-27^{\circ} \mathrm{C}$ berarti ada penurunan sekitar $10^{\circ} \mathrm{C}$. Pada 30 menit pertama bayi dapat mengalami penurunan suhu $3-4^{0} \mathrm{C}$. Pada ruangan dengan suhu $20-25^{\circ} \mathrm{C}$ suhu kulit bayi turun sekitar $0,3^{0} \mathrm{C}$ per menit. Kemampuan bayi baru lahir tidak stabil dalam mengendalikan suhu secara adekuat, bahkan jika bayi lahir saat cukup bulan dan sehat sehingga sangat rentan untuk kehilangan panas. Dengan kemampuan bayi yang belum sempurna dalam memproduksi panas maka bayi sangat rentan untuk mengalami hipotermia. Bayi yang hipotermia akan menggunakan cadangan glikogennya dengan cepat sehingga dapat terjadi hipoglikemia dan ahirnya otak tidak lagi mendapat nutrisi glikogen yang dapat mengakibatkan kejang pada bayi ${ }^{1,2}$.

Oleh karena itu pemantauan lewat Apgar score pada menit pertama dan kelima harus selalu dilakukan oleh tenaga kesehatan. Apgar score merupakan fetal outcome yang harus selalu dipantau untuk melihat dan mempertahankan kondisi bayi baru lahir dan mendeteksi dini masalah atau komplikasi yang mungkin timbul.

Untuk itu diperlukan asuhan essensial pada bayi baru lahir agar dapat mencegah terjadinya komplikasi dan dapat menyelamatkan nyawa bayi seperti segera mengeringkan tubuh bayi baru lahir dan inisiasi menyusu dini sangat diperlukan untuk upaya bayi dapat bertahan hidup dan menunda semua asuhan lainnya minimal satu jam pertama kelahiran ${ }^{2}$.

Perubahan juga terjadi pada ibu post partum seperti perubahan pada sistem kardiovaskuler, endokrin, uterus dan tanda - tanda vital. Perdarahan yang dialami ibu, kehilangan cairan dan kelelahan selama proses persalinan akan mempengaruhi keadaan umum ibu. Dukungan yang penuh pada ibu akan memampukannya untuk beradaptasi dengan perubahan yang ada. Maternal outcome pada ibu bersalin normal juga harus selalu dalam pemantauan, untuk dapat mendeteksi dini jika ada komplikasi atau masalah yang dapat timbul.

Moberg dalam Moore tahun 2012 mengatakan hormon oksitosin keluar sewaktu dilakukan inisiasi menyusui dini dan memengaruhi peningkatan suhu kulit dada dan tubuh ibu. Saat bayi diletakkan di dada ibu suhu ibu meningkat rata-rata $0,5^{\circ} \mathrm{C}$ sekitar dua menit setelah 
kontak kulit ke kulit dan setelah bayi diangkat dari dada ibu maka suhu ibu menurun $0,5^{\circ} \mathrm{C}$ setelah 10 menit bayi diangkat. Hal ini akan memberikan kemampuan pada ibu untuk memodulasi suhu bayi ${ }^{3,4,5}$.

Hentakan kepala bayi di dada ibu, sentuhan tangan bayi diputing susu dan sekitarnya dan jilatan bayi pada puting susu ibu akan merangsang pengeluaran hormon oksitosin yang juga akan mempengaruhi jaringan otot polos rahim berkontraksi sehingga mempercepat lepasnya plasenta dari dinding rahim dan membantu mengurangi perdarahan setelah melahirkan ${ }^{5}$.

Inisiasi menyusu dini (IMD) adalah proses bayi menyusu segera setelah dilahirkan dengan air susu ibunya sendiri dalam satu jam pertama kelahiran. Berdasarkan data Riskesdas tahun 2013, didapati persentase inisiasi menyusu dini kurang dari satu jam sebanyak 34,5\% meningkat dari 29,3 \% pada tahun 2010. Walaupun data IMD mengalami peningkatan dari tahun 2010 namun persentasenya masih sangat rendah dan hal ini menunjukkan bahwa pelaksanaan inisiasi menyusu dini masih sangat jauh dari target yang diharapkan. Padahal manfaat iniasiasi menyusu dini pada 1 jam pertama kelahiran sangat banyak bila dilakukan dengan tepat baik bagi bayi baru lahir maupun bagi ibu post partum ${ }^{2,6,7}$.

Oleh karena itu penelitian ini bertujuan mengetahui pengaruh inisiasi menyusu dini terhadap fetal outcome.

\section{METODE}

Jenis Penelitian ini adalah observasional analitik dengan desain cross sectional untuk mengetahui pengaruh inisiasi menyusu dini terhadap fetal dan maternal outcome.

Tempat penelitian adalah di Rumah Bersalin Anita Agustini. Waktu penelitian dilakukan selama tiga bulan.

Populasi dalam penelitian ini adalah semua ibu post partum dan bayi baru lahir di Rumah Bersalin Anita Agustini.

Sampel yang dipilih adalah Sampel pada penelitian ini adalah semua populasi yang memenuhi kriteria inklusi dan eksklusi.

Kriteria inklusi dalam penelitian ini adalah: Bayi baru lahir normal (tidak ada kelainan)

Kriteria eksklusi adalah bayi letak bokong, persalinan lama/macet dan komplikasi pada bayi.

Kategori kelompok kontrol adalah sesuai kriteria inklusi dan eksklusi dan pada ibu yang menolak untuk melakukan inisiasi menyusu dini. Besar sampel ditentukan dengan menggunakan rumus dari Sastroasmoro ${ }^{8}$ dengan menggunakan nilai standar deviasi dari penelitian sebelumnya. Sampel ditentukan sebanyak 36 orang bayi baru lahir. 18 peserta yang melaksanakan IMD dan 18 peserta yang di observasi tidak melaksanakan IMD. Prosedur penelitian diawali dengan membuat Informed Consent/Persetujuan keluarga bayi baru lahir. Untuk mengetahui Apgar score dan suhu tubuh bayi dilakukan dengan menghitung Apgar Score dan suhu aksila sebelum dan sesudah IMD pada kedua kelompok bayi. Bayi yang tidak di IMD diberikan asuhan bayi baru lahir normal dan dilakukan rawat gabung dengan ibunya

Data di analisis secara uji Mann_Whitney untuk membandingkan data pre - test dan post - test.

\section{HASIL DAN PEMBAHASAN}

Tabel 1 Karakteristik Responden

\begin{tabular}{llcc}
\multicolumn{1}{c}{ Karakteristik } & $\begin{array}{c}\text { IMD } \\
\text { Rerata } \pm \text { SD }\end{array}$ & $\begin{array}{c}\text { Non IMD } \\
\text { Rerata } \pm \\
\text { SD }\end{array}$ & $p$ \\
Bayi baru lahir: & & & \\
Berat Badan (BB) & $3,4 \pm 0,8$ & $3,5 \pm 0,2$ & $p>0,05$ \\
Apgar Score 1 & $7,3 \pm 0,6$ & $7,3 \pm 0,6$ & $p>0,05$ \\
Menit & & $36,7 \pm 0,2$ & $p>0,05$ \\
Suhu Aksila bayi & $36,7 \pm 0,1$ & &
\end{tabular}

Tidak terdapat perbedaan signifikan pada karakteristik antara kelompok intervensi dan kelompok kontrol.

Tabel 2 Pengaruh IMD Terhadap Rerata \pm SD Apgar Score 5 Menit Post Partum

\begin{tabular}{llll}
\hline & \multicolumn{1}{c}{ Rerata \pm SD } & $P$ & \\
IMD & $9,8 \pm 0,3$ & & 0,001 \\
Non IMD & $9,3 \pm 0,4$ & & \\
\hline
\end{tabular}

Tabel 2 menunjukkan rerata Apgar Score menit kelima Post partum pada kelompok IMD lebih tinggi dari pada kelompok non IMD. Rerata Apgar Score pada kelompok IMD adalah 9,8 \pm 0,3 dan rerata apgar score pada kelompok non IMD adalah 9,3 $\pm 0,4$. Secara statistik dengan teknik Mann-Whitney terdapat perbedaan bermakna dengan $p$ value $0,001(>0,05)$.

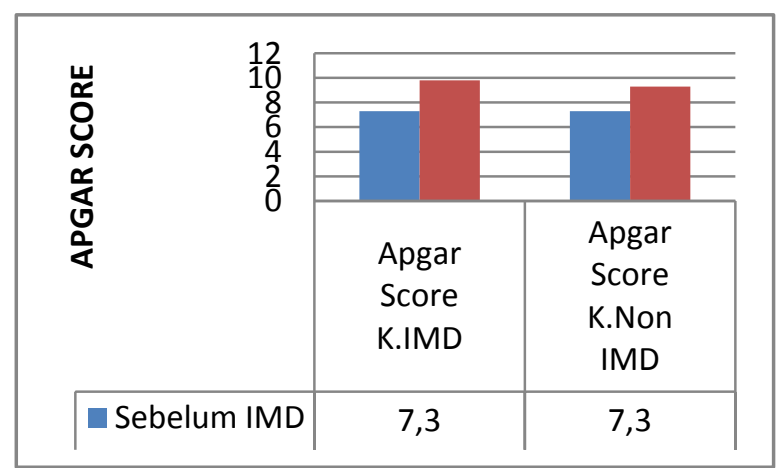

Gambar 1 Rerata Apgar Score Menit Kelima Pada kelompok IMD dan Kelompok Non IMD

Tabel 3 Pengaruh IMD Terhadap Rerata \pm SD Suhu Aksila Bayi Pasca IMD

\begin{tabular}{llll}
\hline & Rerata \pm SD (Menit) & \\
& Suhu aksila 1 jam & \\
& persalinan & & \\
IMD & $37,2 \pm 0,1$ & & 0,020 \\
Non IMD & $37,0 \pm 0,2$ & & 0,20 \\
\hline
\end{tabular}

Tabel 3 menunjukkan rerata suhu aksila bayi setelah 1 jam persalinan pada kelompok IMD lebih tinggi dari pada kelompok non IMD. Rerata suhu aksila bayi pada kelompok IMD adalah $37,2 \pm 0,1^{\circ} \mathrm{C}$ dan rerata suhu 
aksila bayi pada kelompok non IMD adalah $37,0 \pm 0,2^{\circ} \mathrm{C}$. Secara statistik dengan teknik Mann-Whitney terdapat perbedaan bermakna dengan $p$ value $0,020(<0,05)$.

Pada gambar 2 diperlihatkan gambar perbandingan Suhu Aksila Bayi 1 Jam Persalinan pada kelompok IMD dan non IMD.

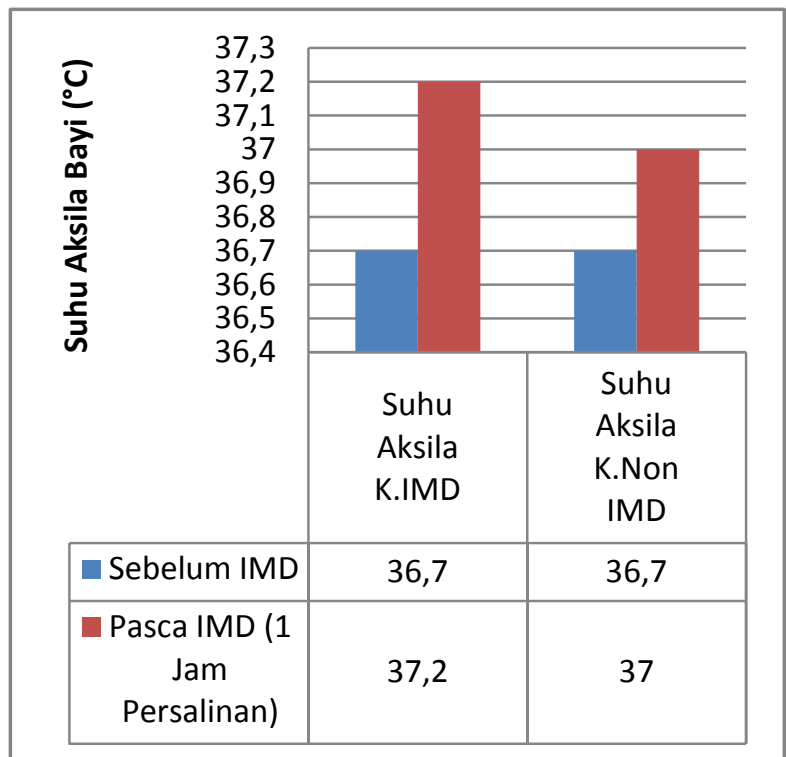

Gambar 5.2 Rerata Suhu Aksila Bayi 1 Jam Persalinan Pada kelompok IMD dan Kelompok Non IMD

Pada penelitian ini didapatkan responden pada kelompok IMD rerata Apgar Score menit kelima pada kelompok IMD lebih tinggi dari pada kelompok non IMD. Rerata Apgar Score pada kelompok IMD adalah 9,8 \pm 0,3 dan rerata apgar score pada kelompok non IMD adalah 9,3 $\pm 0,4$. Secara statistik dengan teknik Mann-Whitney terdapat perbedaan bermakna dengan $p$ value 0,001 (> 0,05).

Pada penelitian ini didapatkan hasil bahwa setelah dilakukan inisiasi menyusu dini rerata apgar score lebih tinggi bila dibandingkan pada kelompok non IMD. Skor apgar lebih tinggi 0,5 pada kelompok IMD dibandingkan pada kelompok non IMD.

Hal ini menunjukkan bahwa inisiasi menyusu dini (IMD) yang dilakukan pada bayi baru lahir mempunyai pengaruh yang sangat baik untuk dapat mempengaruhi percepatan adaptasi bayi baru lahir. Apgar score merupakan pengukuran untuk melihat tingkat kesejahteraan bayi baru lahir, melalui warna kulit, denyut jantung, mimik bayi, aktivitas bayi dan pernapasan bayi pada menit pertama dan kelima. Saat dalam kandungan seluruh kebutuhan janin masih bergantung pada ibunya, namun setelah lahir maka bayi harus berjuang sendiri untuk memenuhi kebutuhan tubuhnya, mulai dari usaha bernafas, sistem peredaran darah, metabolisme, pengaturan tubuh dan lain-lain. Dimana usaha ini untuk enam jam pertama merupakan masa kritis pada bayi baru lahir. Apgar score merupakan pengukuran untuk kita dapat mendeteksi dini keadaan kesejahteraan bayi baru lahir ${ }^{9}$.

Pada penelitian ini diperoleh hasil apgar score pada kelompok IMD lebih tinggi dibandingkan kelompok non IMD, pada saat dilakukan inisiasi menyusu dini maka terjadi kontak kulit dengan kulit antara ibu dan bayinya. Pada saat ini akan terjadi transfer panas dari kulit ibu ke kulit bayi sehingga bayi tidak mengalami kehilangan panas yang berlebihan yang akan menstabilkan penggunaan lemak coklat pada tubuhnya dan menstabilkan metabolisme tubuh bayi. Sehingga pengaturan metabolisme, suhu, pernapasan dan sistem peredaran darah bayi akan dapat berjalan dengan baik.

Hal ini sejalan dengan penelitian yang dilakukan oleh Moore tahun 2016 dimana bayi baru lahir yang dilakukan kontak kulit ke kulit memiliki stabilitas sistem kardio-respiratori yang lebih baik dibandingkan kelompok bayi yang tidak dilakukan kontak kulit, yang menjadi parameter stabilitas tiga perubahan fisiologis yang dialami bayi baru lahir 5 .

Penelitian Nolan tahun 2009 dalam Moore 2016 juga mendapatkan hasil dimana denyut jantung bayi yang dilakukan IMD lebih rendah dibandingkan bayi yang dipisahkan dari ibunya. Denyut jantung bayi yang dilakukan IMD lebih rendah 3,05 denyut per menit bila dibandingkan yang tidak ${ }^{5}$.

Bergman tahun 2004 menyatakan dari 18 orang bayi yang dilakukan inisiasi 15 diantaranya memiliki kondisi tubuh yang stabil, sementara dari 13 orang bayi yang tidak dilakukan inisiasi hanya satu yang kondisi tubuhnya tetap stabil, rata-rata mereka mengalami hipotermia, hipoglikemia dan masalah pernapasan. Kondisi tubuh yang dimaksudkan adalah suhu kulit yang diatas $35,5{ }^{\circ} \mathrm{C}$, denyut jantung 100-180x/menit, kadar glukosa darah kurang dari $2,6 \mathrm{mmol} / \mathrm{l}$ dan tidak mengalami gangguan nafas ${ }^{10}$.

Pada penelitian didapatkan hasil rerata suhu aksila bayi setelah 1 jam persalinan pada kelompok IMD lebih tinggi dari pada kelompok non IMD. Rerata suhu aksila bayi pada kelompok IMD adalah 37,2 \pm 0,1 dan rerata suhu aksila bayi pada kelompok non IMD adalah 37,0 $\pm 0,2$. Secara statistik dengan teknik Mann-Whitney terdapat perbedaan bermakna dengan $p$ value $0,020(<0,05)$. Suhu aksila pada kelompok IMD naik dari 0,3 sampai $0,5^{\circ} \mathrm{C}$ dibandingkan kelompok non IMD.

Pengukuran suhu bayi pada aksila sebagai metode pengukuran yang paling sesuai untuk menentukan suhu inti pada bayi baru lahir. Suhu aksila merupakan suhu permukaan yang paling mendekati dengan suhu inti. Suhu tubuh manusia yang paling stabil dapat ditemukan di daerah aksila, sehingga daerah ini sering menjadi tolak ukur keadaan tubuh. Pada penelitian ini diperoleh hasil bahwa dengan pelaksanaan IMD maka suhu tubuh bayi meningkat dalam kondisi normal. Hal ini mengindikasikan bahwa termoregulasi bayi tetap terjaga. Pada bayi baru lahir termoregulasi atau pengaturan suhu tubuh baru akan stabil setelah melewati masa adaptasi selama enam jam. Sehingga apabila terjadi penurunan atau peningkatan suhu berlebihan maka akan menggangu termoregulasi suhu tubuh bayi yang akhirnya akan mengakibatkan hipotermi atau hipertemi pada bayi. Bila kondisi terus berlangsung maka bayi akan jatuh keadaan yang akan membahayakan bayi. Saat bayi dilakukan inisiasi maka transfer panas dari kulit ibu terjadi membuat bayi tetap hangat bukan panas 
berlebihan, sehingga suhu tubuhnya akan cenderung stabil $^{1,11}$.

Penelitian ini sejalan dengan hasil penelitian yang dilakukan oleh Cristensson tahun 1995 dan Luong tahun 2015 yang mendapatkan hasil peningkatan suhu bayi saat dilakukan inisiasi selama 90 menit sampai 2,5 jam sebesar $0,13-0,47^{\circ} \mathrm{C}$. Suhu tubuh bayi berada di rentang 36,4 sampai dengan $37,1^{\circ} \mathrm{C}^{12,13}$.

Senada dengan penelitian yang dilakukan oleh Vilalon tahun 1992 dimana suhu tubuh bayi yang dilakukan inisiasi meningkat sampai $0,10^{\circ} \mathrm{C}$ dibandingkan kelompok bayi yang tidak dilakukan inisiasi ${ }^{14}$.

Penelitian ini sejalan dengan Fransson tahun 2013 yang mendapatkan peningkatan suhu tubuh inti $0,7^{0} \mathrm{C} /$ jam dengan rerata suhu rektal $36,3^{\circ} \mathrm{C}$ selama kontak kulit ke kulit ibu dan bayi. Pengaturan suhu pada bayi baru lahir normal dapat di evaluasi melalui suhu permukaan dan suhu inti, biasanya dibawah kondisi standar karena anak dipisahkan dari suhu lingkungan normalnya sendiri. Bila tidak dilakukan upaya untuk mempertahankan suhu yang hangat pada lingkungan maka dapat terjadi penurunan pada hari pertama terutama disebabkan pengaturan termoregulasi yang belum sempurna pada bayi baru lahir. Secara bertahap terjadi peningkatan metabolisme basal dan peningkatan kemampuan produksi panas selama hari pertama kelahiran.

Kontak kulit ke kulit harus dilanjutkan sampai akhir dari menyusu pertama untuk menunjukkan efek dan meningkatkan regulasi bayi baru lahir secara dini. Menyusui secara dini selama 30 menit dapat menginduksi pembentukan panas pada bayi baru lahir. Efek termic dari menyusui dapat diperhitungkan yaitu melalui penyimpanan panas dan kemudian dipergunakan ${ }^{5}$.

\section{SIMPULAN}

Berdasarkan hasil analisis data dapat disimpulkan bahwa inisiasi menyusu dini berpengaruh terhadap apgar score dan suhu aksila bayi.

\section{DAFTAR RUJUKAN}

1. Kliegman RM. Janin dan bayi neonatus. Dalam: Ilmu kesehatan anak nelson. Edisi ke-15, vol.1. Editor edisi bahasa Indonesia: Wahab AS. Jakarta: EGC; 2012. Hal. 535-541.

2. WHO. Breastfeeding-early initiation. 2013. Diunduh dari http: // www. who. int/ elena/ titles/early breastfeeding/en/eLENA.

3. Karlsson H. Skin to skin care: heat balance. Sweden: Archives if disease in childhood. 1996; 75:F130-F132.

4. Bergstrom A, Okong P, Arvdson RAB. Immediate maternal thermal respons to skin to skin care of newborn. Acta paediatr. 2007: 96(5):655-8. http:// onlinelibrary. wiley.com/doi/10.1111/j.16512227.2007.00280.x/ abstract;jsessionid.
5. Moore ER, Bergman N, Anderson GC, Medley N. Early skin-to-skin contact for mothers and their healthy newborn infants. Cochrane Database of Systematic Reviews. 2016. http://onlinelibrary.wiley. com/doi/10.1002/14651858.CD003519.pub4/ abstract.

6. Kemenkes. Riset Kesehatan Dasar. Jakarta: Badan Penelitian Dan Pengembangan Kesehatan Kementerian Kesehatan RI. 2013.

7. Kemenkes. Riset Kesehatan Dasar. Jakarta: Badan Penelitian Dan Pengembangan Kesehatan Kementerian Kesehatan RI. 2010.

8. Sastroasmoro S. Dasar-dasar Metodologi penelitian klinis. Jakarta: CV.Sagung seto. 2011.

9. Fraser DM, Cooper MA. Buku ajar bidan myles. Ed 14. Jakarta: EGC; 2009. Hal. 690-693.

10. Bergman N. Restoring the original paradigm for infant care and breastfeeding. Kangaroo mother care. Niels and Jill Bergman Production. 2005

11. McHugh MK. Transisi fisiologis ke kehidupan ekstrauteri. Dalam: Varney H,Kriebs JM, Gegor CL, editor. Buku ajar asuhan kebidanan. Ed 4. Jakarta: EGC; 2008. p.878-888.

12. Christensson K, Cabrera T, Christensson E, Uvnas Moberg K, Winberg J. Separation distress call in the human neonate in the absence of maternal body contact. Acta Paediatrica 1995;84(5):468-73.

13. Luong KC, Nguyen TL, Thi DHH, Carrara HPO, Bergman NJ. Newly born low birthweight infants stabilise better in skin-to-skin contact than when separated from their mothers: a randomised controlled trial. Acta Paediatrica 2015.

14. Villalon HU, Alvarez PC, Barria EH, Caneleo DH, Carrillo LM, Duran SG. Effect of early skin-toskin contact on temperature regulation, heart rate, and respiratory rate in healthy, full-term newborns [Contacto precoz piel a piel: efecto sobre los parametros fisiologicos en las cuatro horas posteriores al parto en recien nacidos de termino sanos]. Revista Chilena de Pediatria 1992;63(3):1404. 